Swarthmore College

Works

Fall 2017

\title{
Introduction To Research Methods In The Social Sciences (SOCI 016B) Syllabus
}

Daniel Laurison

Swarthmore College, dlauris1@swarthmore.edu

Follow this and additional works at: https://works.swarthmore.edu/dev-dhgrants

Part of the Sociology Commons

\section{Recommended Citation}

Daniel Laurison. (2017). "Introduction To Research Methods In The Social Sciences (SOCI 016B)

Syllabus". Introduction To Research Methods In The Social Sciences. DOI: 10.24968/

2476-2458.dhgrants.1

https://works.swarthmore.edu/dev-dhgrants/1

\section{(c) (7)}

This work is licensed under a Creative Commons Attribution 4.0 License.

This work is brought to you for free by Swarthmore College Libraries' Works. It has been accepted for inclusion in Digital Humanities Curricular Development by an authorized administrator of Works. For more information, please contactmyworks@swarthmore.edu. 


\title{
Research Methods in Social Science SOCI 016B - Fall 2017 \\ Daniel Laurison
}

\author{
Tuesdays \& Thursdays, 9:55 - 11:10am, Kohlberg 228 \\ Office Hours: Tuesdays 1pm - 3pm, Kohlberg 239 http://bit.ly/LaurisonOH \\ and by appointment at other times
}

\section{Course Description}

This course is dedicated to understanding how sociologists, anthropologists, political scientists, and scholars in related disciplines analyse, interpret, and make sense of the social world. We will begin with broad questions about knowledge production that undergird our approach to any sociological (or related) inquiry. We will next learn about and practice both qualitative and quantitative research methods, including digital content analysis, interviewing, and survey research. As part of the course, students will learn the rudiments of using statistical software for analysing survey responses; no prior training in statistics is required (or expected). The goals of this course are for you to:

1. Develop your own empirical research question(s) and ability to find answers.

2. Understand how social scientists generate our knowledge about the social world, and why we do it the ways we do.

3. Know how to use a variety of tools and approaches to assist in your (or others') research.

\section{Course Readings \& Resources}

Required Book: Salsa Dancing Into the Social Sciences by Kristin Luker.

Other readings will be on Moodle (or linked from Moodle). We will also use some of OpenIntro Statistics, $3^{\text {rd }}$ Edition, available for free: https://www.openintro.org/stat/textbook.php?stat book=os (site also has links to buy the book if you like), and some trainings in DataCamp.

\section{Assignments/Grading Breakdown}

\begin{tabular}{|c|c|c|}
\hline Due Date & Assignment & $\%$ of Grade \\
\hline All semester & Class Participation \& Attendance & $10 \%$ \\
\hline All semester & Research development credit/no credit assignments & $5 \%$ \\
\hline Tuesday September $19^{\text {th }}$ & Initial Research Question & $10 \%$ \\
\hline Thursday October $3^{\text {rd }}$ & Pilot/Practice Digital Content Analysis & $10 \%$ \\
\hline Thursday October $12^{\text {th }}$ & Annotated Bibliography & $10 \%$ \\
\hline Thursday October $26^{\text {th }}$ & Pilot/Practice Interview or Ethnography Report & $10 \%$ \\
\hline October \& November & Quantitative Homeworks (4, credit/no credit) & $5 \%$ \\
\hline Thursday November $30^{\text {th }}$ & Pilot/Practice Survey Report & $15 \%$ \\
\hline End of Semester & Final research proposal & $25 \%$ \\
\hline
\end{tabular}




\section{Course Policies}

Office Hours: You are strongly encouraged to come to my office hours to discuss your research ideas in advance of any assignment. Office hours are also available for anything class-related you'd like to discuss or ask questions about. If you are having trouble with any aspect of the course, please see me as early as possible; it's much easier for me to help you if you alert me of difficulties early on. On Tuesdays, you may reserve a time slot at www.swarthmore.edu/officehours or you can just drop by. If you do reserve a spot, PLEASE either show up or cancel the meeting. I am happy to meet with you at other days or times if you can't make my scheduled office hours or need to talk with me later in the week. In that case, please email me to set up a meeting, and include a range of possible times in your message. You can also come by my office; if my door is all the way open that means I'm available, but if it is closed or mostly closed I'm working and would prefer not to be disturbed except for quick and/or urgent matters.

Contacting me: The best way to reach me is email; I will be available if you need to contact me for any reason; you can expect a response within 24 hours during the week and by Monday morning if you email over the weekend.

Grading Policy: Please try not to worry too much about your grade, and just do your best and learn the most you can. However, you will be getting grades on most of your assignments, and a final grade. Generally, work that does everything I expect reasonably well is a B, not an A. Work that is exceptionally good/excellent may receive an A; work that is flawed in some ways but still substantially meets the expectations laid out in the assignment is generally a $\mathrm{C}$, and work that is substantially flawed is a $\mathrm{D}$ or below.

Moodle: You can find all readings on (or linked to from) Moodle. I will also use our course Moodle for announcements and updates, including an up-to-date version of the syllabus should there be any changes. You are responsible for reading everything posted on the course site and/or sent to you by email.

Laptop and Phone Use: It is very easy to distract yourself with technology/social media instead of being fully present during class, but that is rude to your colleagues and to me. So: phones must be kept out of sight and on silent mode during class, and when you are using a computer during class, please use it ONLY for class-related purposes, and set it up so that you are not tempted to take a quick peek at anything else (consider turning the wi-fi off, or even getting a social-media blocking app for use during class times).

Handing in Assignments: Assignments ought to be handed in exactly at the time (beginning of class unless otherwise specified) and the date when they are due. If for any reason this will not be possible, please talk to me as far in advance as you can, and we will work something out. If you miss an assignment due date without communicating with me in advance, I will reduce your grade for that assignment. 
Academic Honesty: Plagiarism is very very bad. Don't do it. It's not worth it. All work you turn in to me should be your own work, created specifically for this class, with nothing copied that is not clearly attributed to its source. Plagiarism is representing the work of others as your own (including copying other students' work or using internet resources without proper citation). If you are unsure what counts as plagiarism or academic dishonesty, come talk to me.

Books \& Readings Policy: You should bring your copy of each day's readings with you to class. I would very much like for you to have a physical copy, but a virtual/electronic version is acceptable. If it will be financially difficult for you to purchase our course book(s), I can provide you with a copy for free; simply let me know you need the book. I only ask that if, after the semester is over, you don't want to continue owning the book, you return it to me rather than selling it so I can loan it to another student.

Statement on Students with Disabilities: If you believe that you need accommodations for a disability, please contact the Office of StudentDisability Services (Parrish 113W) or email studentdisabilityservices@swarthmore.edu to arrange an appointment to discuss your needs. As appropriate, the Office will issue students with documented disabilities a formal Accommodations Letter. Since accommodations require early planning and are not retroactive, please contact the Office of Student Disability Services as soon as possible. For details about the accommodations process, visit the Student Disability Service Website at http://www.swarthmore.edu/academic-advising-support/welcome-to-student-disabilityservice. You are also welcome to contact me [the faculty member] privately to discuss your academic needs. However, all disability-related accommodations must be arranged through the Office of Student Disability Services.

\section{Assignments Details}

Research Development Assignments: These will be assigned especially in the first few weeks of the semester, and towards the end of the semester building towards your final project. They will generally be short, informal writing assignments to be brought to class. You need to do and get credit for each of these to earn this portion of your grade.

Initial Research Proposal/Research Question: Identify a research question you want to answer. Discuss why this question is important substantively, and for sociology and/or anthropology and/or other social sciences. Be as specific as you can be about the location, time period, and population for which you hope to answer your question, and discuss some ways you might find an answer to your questions through the pilot projects over the course of the semester, as well as some possible limitations or pitfalls you might encounter in your research.

Pilot/Practice Digital Content Analysis: Pick a sample of social media content (from Facebook, Twitter, Reddit, Tumblr, or any other social media platform with which you are familiar and that is substantially/primarily text rather than images) that consists of at least 10 posts, tweets, or 
comments totalling at least 250 words. You may do this by simply copying and pasting posts from a web browser, or by using R (or another tool) to grab a sample (screenshotting is OK too but will limit your options for analysis). Choose an analytic strategy: you might hand-code, read holistically, use comments in Word, use software such as Atlas.ti, or calculate sentiment or other attributes using $\mathrm{R}$ (or another tool)? Whatever your approach, you'll hand in three things:

1. A memo of around 750 words describing what you wanted to know or thought you might find, how you chose your sample and why, what you found (be thoughtful about how or whether your findings are generalizable), and how you might improve on it in further research.

2. The text you analysed.

3. Documentation/representation of your coding/analytic strategy. This may be combined with 2, i.e. you might print out a Word document with all the text and the comments where you're making notes about it, or output from $\mathrm{R}$ that includes both the text of tweets you analysed and their sentiment score, etc.

Annotated Bibliography: Choose five articles that meet the criteria below. Read each one, and take notes using the notes feature in Zotero. Your notes can be in narrative/paragraph form or bullet points or any other format that works for you, but must be at least 250 words for each article, including the key points and conclusions, some description of the case/evidence/methods used, and your assessment of the article, including any concerns you have about its methodology, validity, generalizability.

- Published in 2010 or later

- At least two of the five should be in journals in the list below

- At least two (and no more than three) of the articles must use quantitative methods

- One can be a book

- At least one of the five should be from each column below (at least one Sociology, at least one Anthropology)

\begin{tabular}{l|l} 
Sociology & Anthropology \\
\hline American Sociological Review & American Ethnologist \\
\hline American Journal of Sociology & American Anthropologist \\
\hline Social Forces & Cultural Anthropology \\
\hline
\end{tabular}

You will turn in three things:

1. A memo of around 500 words describing how you found your articles, any challenges you ran into, and what your conclusion is about the state of research (broadly) on your question.

2. A grid listing your 5 articles and which of the criteria they meet (template will be provided).

3. A report printed from Zotero showing your notes on each of the 5 articles. 
Pilot in-depth/semi-structured interviews OR Pilot/Practice Ethnography: Choose to do interviews or a mini-ethnography.

- Interviews: Identify at least two people whom you can interview for at least 30-45 minutes each and whose responses might shed some light on your research question. Design an interview guide, a consent form, and record your interviews. Transcribe as much of your interviews (don't spend more than 2 hours on the transcription; it's OK if you don't get them fully transcribed, especially if they ran long).

- Ethnographic/observational study: Identify a site where you can observe or participate in social life in a way that relevant to your research question. Spend at least 2.5 hours there (all at once, or in up to three instalments, depending on what makes the most sense for your site and your research question). Take extensive, detailed field notes, during (if possible) and directly after your observation. You should write as complete a narrative of the time you spent participating/observing as you can, but if you find you've spent more than 3-4 hours writing and have not recounted your whole experience, you can stop.

Whatever your approach, you'll hand in three things (there's a theme here...):

1. A memo of around 750 words describing your experience. You should discuss what you wanted to know or thought you might find, why you thought interviewing or ethnography was your best strategy, how and why you chose your interviewees or your site, what you found (be thoughtful about how or whether your findings are generalizable), and how you might improve on it in further research.

2. Your (as complete as possible) interview transcripts and/or recordings, and

3. Documentation/representation of your coding/analytic strategy. This may be combined with 2, i.e. you might print out a Word document with all the text and the comments where you're making notes about it, or reports from Atlas.ti, etc.

Quantitative Homeworks: There will be a series of credit/no credit assignments related to the quantitative portion of our class, including 4 homeworks/problem sets. You have the option to redo any assignment that doesn't get credit; you'll need to complete all homeworks to get any credit for this portion of your grade.

Pilot survey/stats report: You will analyse data from the survey we create together, and describe your findings. You will turn in a document created in R Markdown that shows the code you used, the results you saw, and your careful description of what those results mean. Your report should include each of the following:

- At least three univariate descriptive statistics of the population you looked at/surveyed, at least two displayed graphically.

- At least three bivariate relationships, at least two displayed graphically.

- One should show the relationship between two categorical variables

- One should show the relationship between a categorical and a continuous variable 
- One should show the relationship between two continuous variables

- At least one multivariate relationship that is not regression.

- At least one regression.

- A discussion of what inferences can be made to a broader population from these results, and your overall conclusions about the findings of the parts of the survey you analysed.

First Research Proposal: Drawing on what you have learned from your readings and pilot studies over the course of the semester, propose a full-fledged research project that could be a senior thesis or similar. You may copy from *your own* work in this class over the course of the semester as much as you like. The proposal should be around 2500 words and include:

- An introduction, stating your research question (it's OK if this has evolved over the semester!), and explaining why it is interesting and important.

- A review of the existing literature on this question, and how your research would add to that literature.

- A "preliminary results" or "methodological preparation" section, reflecting what you learned from your pilot/practice projects.

- A “proposed research" section laying out a specific, achievable research plan, including an explanation of why this research is the best possible way to answer your specific research question, realistic details on how you will gain access to your research site/interviewees/survey data, what you will do with them (ethnography for how long in what way? What will you ask in interviews? How will you analyse survey data? Etc)

- A limitations \& challenges section where you anticipate possible challenges and limitations and explain how you hope to overcome them, or why they are not fatal flaws in your research design.

- A conclusion explaining how the results of your research will add to stocks of social scientific knowledge and maybe even benefit society in some way.

\section{Course Schedule}

Date

Theme Reading

\begin{tabular}{l|r}
$9 / 5$ & Course \\
$9 / 7$ & Whtroduction \\
& \\
& \\
& \\
& \\
& \\
&
\end{tabular}

No Reading

Salsa Dancing, Chapter 1: Salsa Dancing? In the Social Sciences? \&

Appendix 1 What to Do If You Don't Have a Case

Mills, C. Wright. Chapter 1, "The Promise" in The Sociological Imagination. Oxford [England] New York: Oxford University Press, 2000 [1959].

Scheper-Hughes, Nancy. "Can Anthropology Save the World?” Berkeley News, May 24, 2016. 
Date

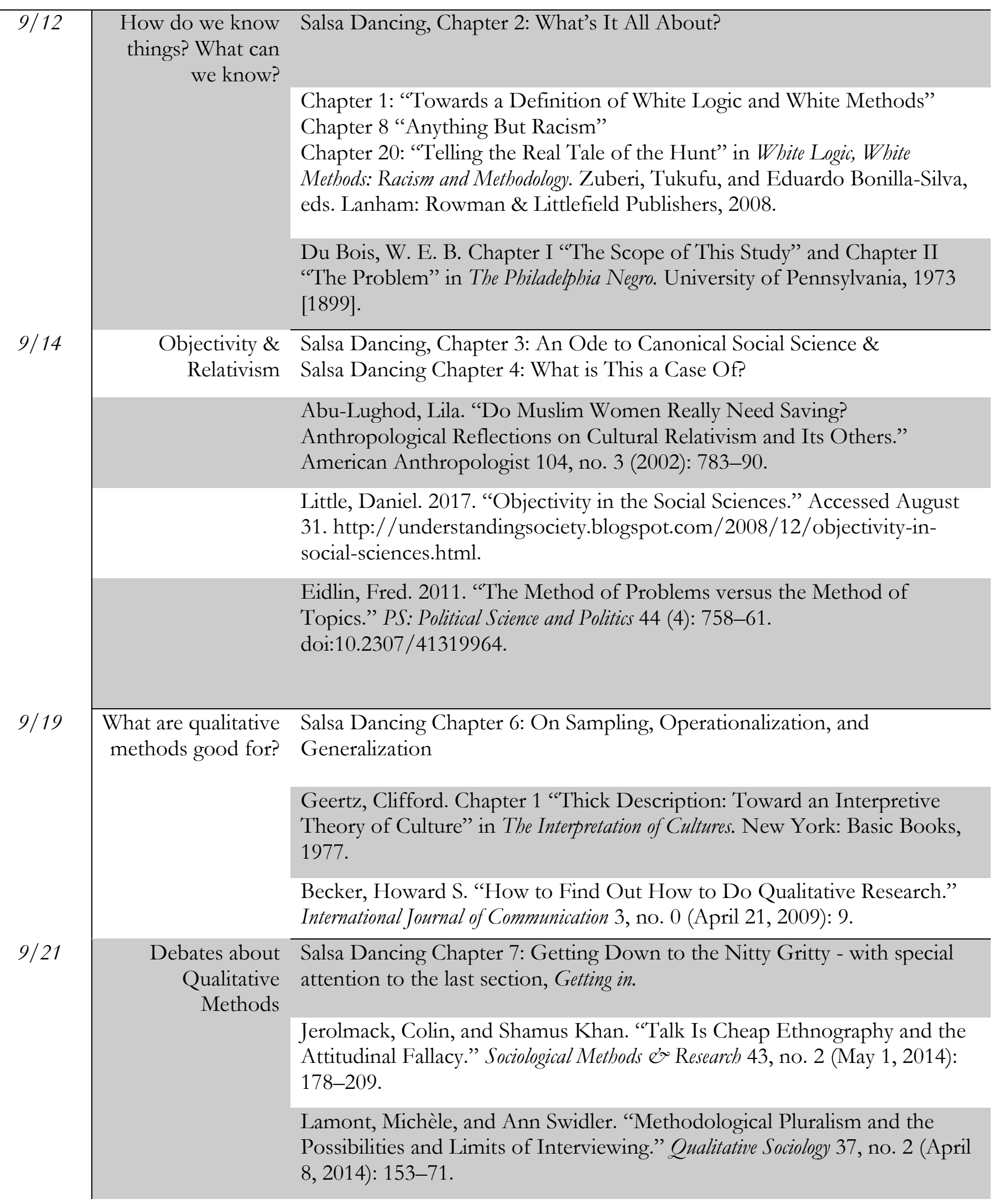


Date

\begin{tabular}{l|r}
$9 / 26$ & $\begin{array}{r}\text { Digital methods - } \\
\text { why? }\end{array}$ \\
$9 / 28$ & $\begin{array}{r}\text { Digital Methods - } \\
\text { how \& examples }\end{array}$
\end{tabular}

Introduction, only through page xxii.

Cottom, Tressie McMillam. 2016. "Black Cyberfeminism: Ways Forward for Intersectionality and Digital Sociology"

Recuber, Timothy. 2016. "Digital Discourse Analysis: Finding Meaning in Small Online Spaces." In Digital Sociologies, edited by Jessie Daniels, Karen Gregory, and Tressie McMillan Cottom, Reprint edition. Bristol Chicago: Policy Press.

Orton-Johnson, Kate, Nick Prior, and Karen Gregory. 2017. "Sociological Imagination: Digital Sociology and the Future of the Discipline." https://www.thesociologicalreview.com/information/blog/sociologicalimagination-digital-sociology-and-the-future-of-the-discipline.html.

Abramson, Corey M., Jacqueline Joslyn, Katharine A. Rendle, Sarah B. Garrett, and Daniel Dohan. 2017. "The Promises of Computational Ethnography: Improving Transparency, Replicability, and Validity for Realist Approaches to Ethnographic Analysis." Ethnography, August.

Haber, Benjamin. 2016. "Queer Facebook? Digital Sociality and Queer Theory".

Williams, Apryl. 2016. "On Thursdays We Watch Scandal: Communal Viewing and Black Twitter"

In Digital Sociologies, edited by Jessie Daniels, Karen Gregory, and Tressie McMillan Cottom, Reprint edition. Bristol Chicago: Policy Press.

How to do Salsa Dancing Chapter 8: Field (and Other) Methods Ethnography

Ali, Syed, and Philip N. Cohen. 2017. "How to Do Ethnography Right Contexts." Contexts Magazine. Accessed August 31. https://contexts.org/blog/how-to-do-ethnography-right/. Lareau, Annette, and Aliya Hamid Rao. 2017. "It's about the Depth of Your Data - Contexts." Contexts Magazine. https://contexts.org/blog/itsabout-the-depth-of-your-data/.

Hoang, Kimberly Kay. Methodological Appendix, "The Empirical Puzzle and the Embodied Cost of Ethnography" in Dealing in Desire: Asian Ascendancy, Western Decline, and the Hidden Currencies of Global Sex Work. Oakland, California: University of California Press, 2015.

AND: skim the rest of the book, and/or read 'Flirting with Capital: Negotiating Perceptions of Pan-Asian Ascendency and Western Decline in Global Sex Work.” Social Problems 61, no. 4 (2014): 507-29. 
Date

\begin{tabular}{|c|c|c|}
\hline \multirow[t]{3}{*}{$10 / 5$} & $\begin{array}{l}\text { How to do } \\
\text { Interviews }\end{array}$ & $\begin{array}{l}\text { Vasquez-Tokos, Jessica. 2017. "If I Can Offer You Some Advice’: Rapport } \\
\text { and Data Collection in Interviews Between Adults of Different Ages." } \\
\text { Symbolic Interaction, April. }\end{array}$ \\
\hline & & $\begin{array}{l}\text { Introduction, esp p. } 8 \text { - 14; ch } 3 \text { "Preparing to Interview" and Optionally } \\
\text { Ch } 4 \text { "Interviewing". Weiss, Robert S. 1995. Learning From Strangers: The } \\
\text { Art and Method of Qualitative Interview Studies. Simon and Schuster. }\end{array}$ \\
\hline & & $\begin{array}{l}\text { Dow, Dawn Marie. "The Deadly Challenges of Raising African American } \\
\text { Boys: Navigating the Controlling Image of the "Thug."' Gender \& Society 30, } \\
\text { no. } 2 \text { (April 1, 2016): 161-88. }\end{array}$ \\
\hline \multirow[t]{2}{*}{$10 / 10$} & Lit Reviews & Salsa Dancing Chapter 5: Reviewing the Literature \\
\hline & & $\begin{array}{l}\text { Gilens, Martin. Selections from Chapter } 1 \text { "Citizen Competence and } \\
\text { Democratic Decision Making" in Affluence and Influence: Economic Inequality } \\
\text { and Political Power in America. Princeton University Press, } 2012 .\end{array}$ \\
\hline \multirow{5}{*}{$\begin{array}{c}10 / 12 \\
10 / 17 \& \\
10 / 19 \\
10 / 24\end{array}$} & $\begin{array}{l}\text { Annotated } \\
\text { Bibliography }\end{array}$ & No reading, read your articles \& write your annotated bibliography. \\
\hline & & FALL BREAK \\
\hline & $\begin{array}{r}\text { What are } \\
\text { Quantitative } \\
\text { Methods Good } \\
\text { for? }\end{array}$ & $\begin{array}{l}\text { King, Gary, Robert O. Keohane, and Sidney Verba. 1994. Designing Social } \\
\text { Inquiry: Scientific Inference in Qualitative Research. Princeton, N.J: Princeton } \\
\text { University Press. }\end{array}$ \\
\hline & & $\begin{array}{l}\text { Bourdieu, Pierre. "Public Opinion Does Not Exist." In Communication and } \\
\text { Class Struggle, edited by Armand Mattelart and Seth Siegelaub, 1:124-30, } \\
1979 .\end{array}$ \\
\hline & & $\begin{array}{l}\text { Laurison, Daniel. 2015. “The Willingness to State an Opinion: Inequality, } \\
\text { Don't Know Responses, and Political Participation.” Sociological Forum, } \\
\text { September, 925-48. }\end{array}$ \\
\hline \multirow[t]{2}{*}{$10 / 26$} & Surveys & $\begin{array}{l}\text { Westbrook, Laurel, and Aliya Saperstein. 2015. "New Categories Are Not } \\
\text { Enough Rethinking the Measurement of Sex and Gender in Social } \\
\text { Surveys." Gender \& Society } 29 \text { (4): 534-60. }\end{array}$ \\
\hline & & $\begin{array}{l}\text { "Chapter 2: Designing Questions to Gather Factual Data." In Fowler, Floyd } \\
\text { J. 1995. Improving Survey Questions: Design and Evaluation. SAGE. }\end{array}$ \\
\hline $10 / 31$ & Survey Design Day & no reading, we'll go over our survey draft together \\
\hline
\end{tabular}




\section{Date Theme Reading}

\begin{tabular}{|c|c|c|}
\hline $11 / 2$ & $\begin{array}{r}\text { Univariate } \\
\text { Descriptive } \\
\text { Statistics \& Graphs }\end{array}$ & $\begin{array}{c}\text { In this section, we will use selections from the OpenIntro Stats book } \\
\text { (available free online or very low cost if you want the actual book), and } \\
\text { modules from DataCamp }\end{array}$ \\
\hline $11 / 7$ & & Bivariate Tables \& Graphs 1 \\
\hline $11 / 9$ & & Bivariate Tables \& Graphs \\
\hline $11 / 14$ & & Comparing groups, multivariate analyses \\
\hline $11 / 16$ & & Comparing groups, multivariate analyses \\
\hline $11 / 21$ & & Introducing Regression \\
\hline $11 / 23$ & & NO CLASS THANKSGIVING \\
\hline $11 / 28$ & $\begin{array}{r}\text { More on } \\
\text { Regression }\end{array}$ & $\begin{array}{l}\text { Laurison, Daniel, and Sam Friedman. "The Class Pay Gap in Higher } \\
\text { Professional and Managerial Occupations." American Sociological Review 81, } \\
\text { no. } 4 \text { (August 1, 2016): 668-95. }\end{array}$ \\
\hline & & $\begin{array}{l}\text { Aschwanden, Christie. 2015. "Science Isn't Broken." FiveThirtyEight. } \\
\text { August 19. https:// fivethirtyeight.com/ features/science-isnt-broken/. }\end{array}$ \\
\hline $11 / 30$ & Ethics & $\begin{array}{l}\text { Murphy, Alexandra, and Colin Jerolmack. 2017. "Ethnographic Masking in } \\
\text { an Era of Data Transparency - Contexts." Contexts Magazine. } \\
\text { https://contexts.org/blog/ethnographic-masking-in-an-era-of-data- } \\
\text { transparency-2/. }\end{array}$ \\
\hline $12 / 5$ & Other methods & Salsa Dancing Ch 9: Historical Comparitive Methods \\
\hline $12 / 7$ & Wrapping Up & Salsa Dancing Ch 10: Data Reduction and Analysis \\
\hline $12 / 12$ & Wrapping Up & Salsa Dancing Ch 11: Living Your Life as a Salsa Dancing Social Scientist \\
\hline
\end{tabular}

